\title{
DEPOSITIONAL MODEL OF NGRAYONG FORMATION IN MADURA AREA, NORTH EAST JAVA BASIN, INDONESIA
}

\author{
Paike Htwe $^{* 1,2}$, Sugeng Sapto Surjono ${ }^{2}$, Donatus Hendra Amijaya ${ }^{2}$, and Kyuro Sasaki ${ }^{3}$ \\ ${ }^{1}$ Geology Department, Magway University, Magway, Myanmar \\ ${ }^{2}$ Department of Geological Engineering, Gadjah Mada University, Yogyakarta, Indonesia \\ ${ }^{3}$ Department of Earth Resources Engineering, Faculty of Engineering, Kyushu University, Fukuoka, Japan
}

\begin{abstract}
The early Middle Miocene Ngrayong Formation, an important reservoir of North East Java Basin, is well exposed in the central anticlinal part of Madura Island. The purpose of current study is to classify the depositional environments of the study area based on the characteristics and geometry of sedimentary facies. In the Madura island, the thicker clastics and deeper carbonates of Ngimbang Formation and Kujung Formation of Late Oligocene-Early Miocene deposited in the northeast-southwest asymmetrical half grabens. After the deposition of Kujung Formation, the basin morphology developed nearly eastwest trending shelf edge and the deposition of Tuban Formation began. The fine grained complex of Tuban Formation was followed by the Ngrayong Sandstones deposition. The depositional model of Ngrayong Formation is being producing of wide variety of depositional environments. Large scale cross-bedded sandstones and bioturbated massive sandstones with thin to medium bedded argillaceous limestone that outcrop in the northern part of the study area are deposited in costal environment. The heterolithic sandstone with planar and trough cross-lamination, fine grained sandstone with interlaminated structure and bioclastic carbonate exposed in the central part of the study area are deposited in upper shallow marine area. Dark grey siltstones and mudstones
\end{abstract}

\footnotetext{
*Corresponding author: P. HTWE, Department of Geological Engineering, Gadjah Mada University. Jl. Grafika 2 Yogyakarta, Indonesia. E-mail: ph.geology.mgu@gmail.com
}

deposited in lower shallow marine area are well exposed in southern part of the study area. In conclusion, Ngrayong Formation in Madura area is developed in three depositional units which are coastal, upper shallow marine and lower shallow marine.

Keywords: Lithofacies, Depositional environment, Sandstone, Ngrayong Formation, Madura Island, North East Java Basin

\section{Introduction}

The North East Java Basin, a classic back-arc basin, is situated on the southern margin of the stable Sunda craton. The East Java region can be grouped into five tectonic provinces (Yulihanto et al., 1995). The study area, Madura Area is situated in the eastern part of Rembang Zone, the northernmost province of East Java. The Rembang Zone sequence was strongly influenced by Tertiary clastics and carbonates that form large petroleum reservoirs (Soetantri et al., 1973). Geomorphologically, the study area is regarded as hilly topographic terrain forming continuous ridges of relatively low relief (Figure 1). Many valleys with various sizes dissected the area in nearly E-W direction.

The hydrocarbon exploration in North East Java Basin, including the study area, had started by Dutch companies during Dutch colonization (before 1940s). The Dutch author, Bouwens (1938), described that the Ngrayong Formation was fully marine deposits base on fossils evidences. However, later authors 


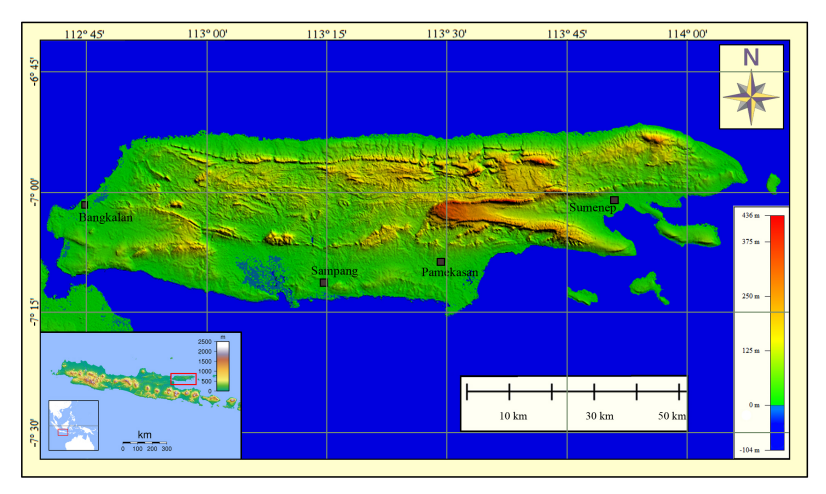

Figure 1: The Location and topographic map of Madura Area.

such as Brouwer (1957) noted very shallow to marginal marine deposits for this formation. Latief et al. (1990) interprets that the deposition area of Ngrayong Formation in Madura area was the deltaic origin. Ardhana (1993) concluded, the Ngrayong Formation was deposited on the continental shallow shelf to slope areas. The authors who studied the Ngrayong Formation mentioned that Ngrayong Formation was deposited on various kinds of environment and a number of sedimentary processes. The purpose of the present study is to identify the depositional setting of Ngrayong Formation based on variation and distribution of sedimentary facies.

\section{Materials and Methods}

The Ngrayong Formation is generally exposed along east-west trending in the central anticlinal part of the study area (Figure 2). A number of good outcrops are situated at the quarries along the flanks of Madura Anticline, and on the way connected from the Pamekasan to the north coast of Madura (Figure 2). Seven quarries and one road sections are measured in the study area. The thickness of the section was directly measured by Jacob's Staff and the dip and strike of the strata was measured by Brunton Compass. The other field equipment such as Global Positioning System (GPS) to take locations, camera to take photographs and hammer are also used in the field. The stratigraphic columns were reproduced by using Surfer 10 software after the field study. The depositional environments are classified based on the characteristic of sedimentary units which include thickness, sedimentary structures, grain sizes and types, colour and biogenic content of the sedimentary rock.

\section{Geological background}

The Ngrayong Formation is mainly composed of quartzarenite sandstones in Madura Island, and shales and sandstones in the Rembang and Randublatung zone. The sandstones are productive in the onshore East Java Basin (Soetantri et al., 1973; Sharaf et al., 2005). These sandstones are medium- to coarse-grained and moderately to well sorted and exhibit excellent reservoir properties with porosity greater than $35 \%$ and permeability's up to 10 Darcy (IBS, 2006).

The upper boundary of Ngrayong Formation is represented by an erosion surface, with meter-scale conglomerate-filled channels which are overlain by the late Middle Miocene Bulu Formation, a marker bed consisting of massive carbonates rich in larger benthic foraminifera and small patches of corals, red algae and sandy carbonates. The lower boundary between the Ngrayong Formation and late Early Miocene Tuban lithologies is generally gradational contact. However, it is locally represented by a few centimeters of glauconitic and broken and stained skeletal grains, suggesting sediment starvation and possible drowning (Sharaf et al., 2005). The age of Ngrayong Formation is ranging from early Middle Miocene to mid-Middle Miocene (J.O.B. Pertamina-Trend Tuban, 1990). Strontium isotope data indicate that the age of Ngrayong Formation constrains between 15 and $13 \mathrm{Ma}$ (Sharaf et al., 2005).

\section{Paleogeography}

The basement architecture of North East Java Basin is northeast-southwest asymmetrical half grabens and ridges (Darman and Sidi, 2000). In Late Oligocene-Early Miocene, the thicker clastic and deeper carbonate of Ngimbang Formation and Kujung Formation accumulated in the 


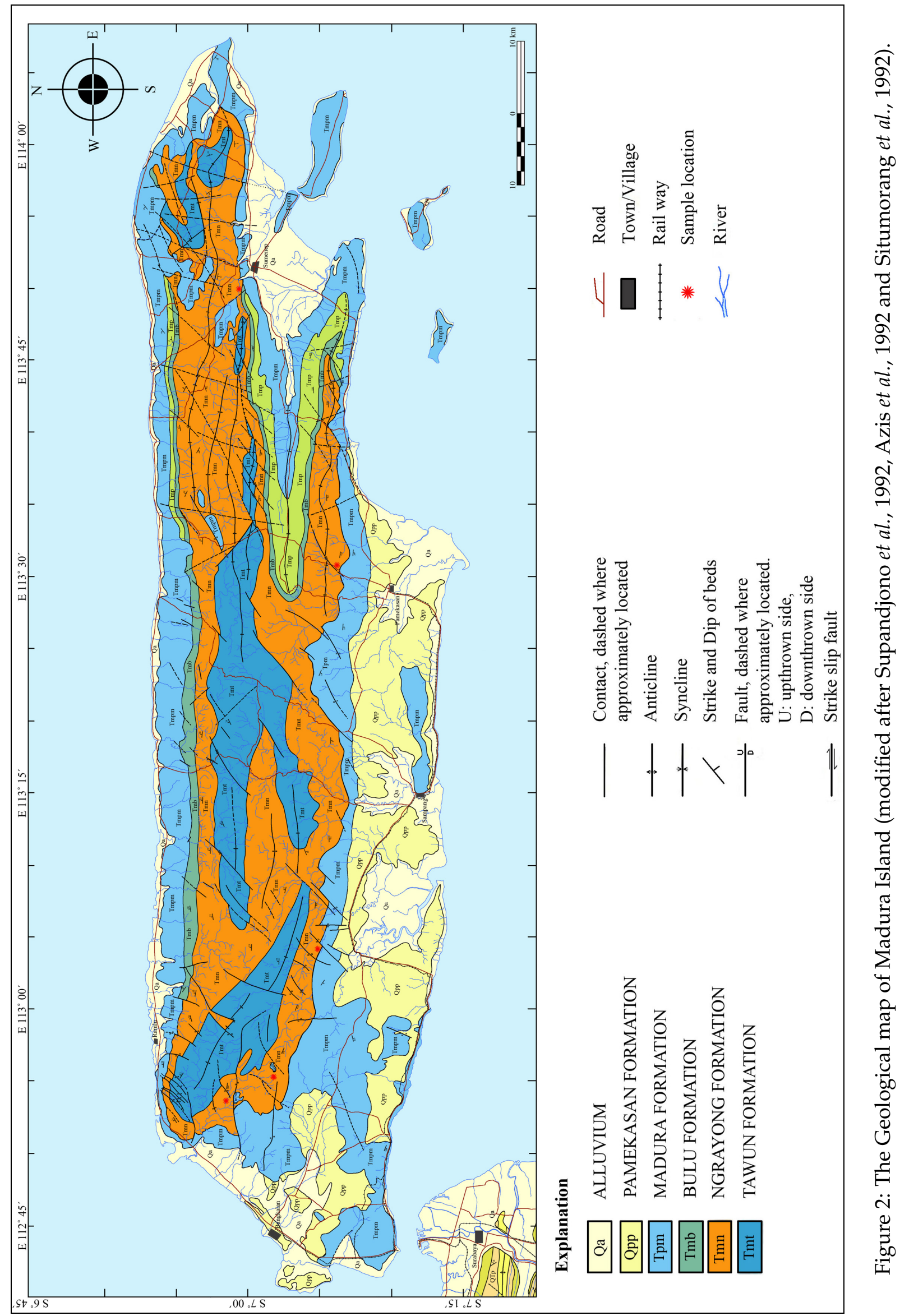


half grabens. The reefal carbonate sediments are developed on the ridges at the same time.

The basin was divided by an irregular eastwest trending shelf edge, after the deposition of Kujung Formation (Ardhana, 1993). This structural trend is developed approximately parallel along the present northern coast of East Java and Madura.

The major tectonic readjustment have not been appeared during the deposition of the Tuban Formation which is marked by a relatively thin clastic sequence on the shelf while bathyal shales accumulated and partially filled the lows to the south. This deposition was the regional setting prior to the deposition of the Ngrayong Formation (Ardhana, 1993).

\section{Depositional setting}

In the current study, the depositional model of Ngrayong Formation establish based on lithofacies distribution and depositional environments. Seven quarries and one road sections are measured to classify lithofacies and to interpret depositional environment of its. Those eight sections (Figure 3) were AB (quarry near Ambunten River in northeastern part of Madura Anticline), CPG (quarry at Campor Geger village in the north-east of Bankalan), GGL (quarry at Geger Gujug Laut village), SP (quarry at $19 \mathrm{~km}$ from the north-west of Sampang), SMN (quarry at $3 \mathrm{~km}$ from north-west of Sumenep), PMK (quarry in Pamekasan), KRK (Karukan quarry in northeastern part of Pamekasan) and PMR (road section at the anticlinal part, $18 \mathrm{~km}$ from the due north of Pamekasan).

The model presented three depositional units within the Ngrayong Formation (Figure 3) in Madura Area. These are coastal unit, upper shallow marine unit and lower shallow marine unit. Each units have a different areal extend and sedimentary facies as a consequence of differing depositional environments and sedimentary processes.

\section{Coastal unit}

This unit is well exposed at the quarries in the northern most part of Madura Island (Figure
3) especially in CPG, $\mathrm{AB}$ and the lower part of GGL quarries. The coastal sediments represented by medium- to coarse- grained, generally thickly bedded, locally massive sandstones are cropped out in these quarries. The sandstones are yellowish brown, moderately sorted quartz arenite. Large, planar cross beddings are found in this sandstone (Figure $4 \mathrm{a}$ ). The flaser bedding and mud drape also developed in quartz arenite sandstones (Figure $4 \mathrm{~b}$ ). The parallel laminated sandstones covered over the coarse-grained and thickly bedded quart arenite sediments (Figure 4k) in CPG quarry section (Figure 3). Medium grained thickly bedded quartzose sandstones intercalated with limestone. Limestone intercalations are thinly bedded, hard, argillaceous and fossiliferous. The vertical bioturbations (Figure $4 \mathrm{~d}$ ) are also common within the massive sandstones in AB (Figure 3 ) and GGL sections.

The evidences of tidal current such as mud drapes, flaser bedding and cross bedding are characterized in this unit. The cross-bedded quartz arenite in this area was formed in tide dominated channel to subtidal in regressive situation where the mega ripple sand dune (Endharto, 2004). The vertical burrow structures in the massive sandstones point out the high energy environments. The bedding character, coarse grained and massive sandstones covered by parallel laminated (Figure 3) are occurred in intertidal coast line area (Nichols, 1999; 2009). This unit is, consequently, the tide dominated intertidal to foreshore environment.

\section{Upper shallow marine unit}

This unit is well exposed at the base of Gujug Laut Quarry section (GGL), in northern part of Madura area (Figure 3). This sediments are also seem at SP section, KRK section, PMK section, PMR section and SMN section in the southern part of Madura.

In this unit, fine- to medium- grained, medium sorted, thickly bedded to massive heterolithic sandstones are found at the middle part of GGL section (Figure 3). These sandstones consist of wavy to flaser bedded and thin mud drape. The heterolithic sand beds are intercalated with dark brown, thin- to medium- 


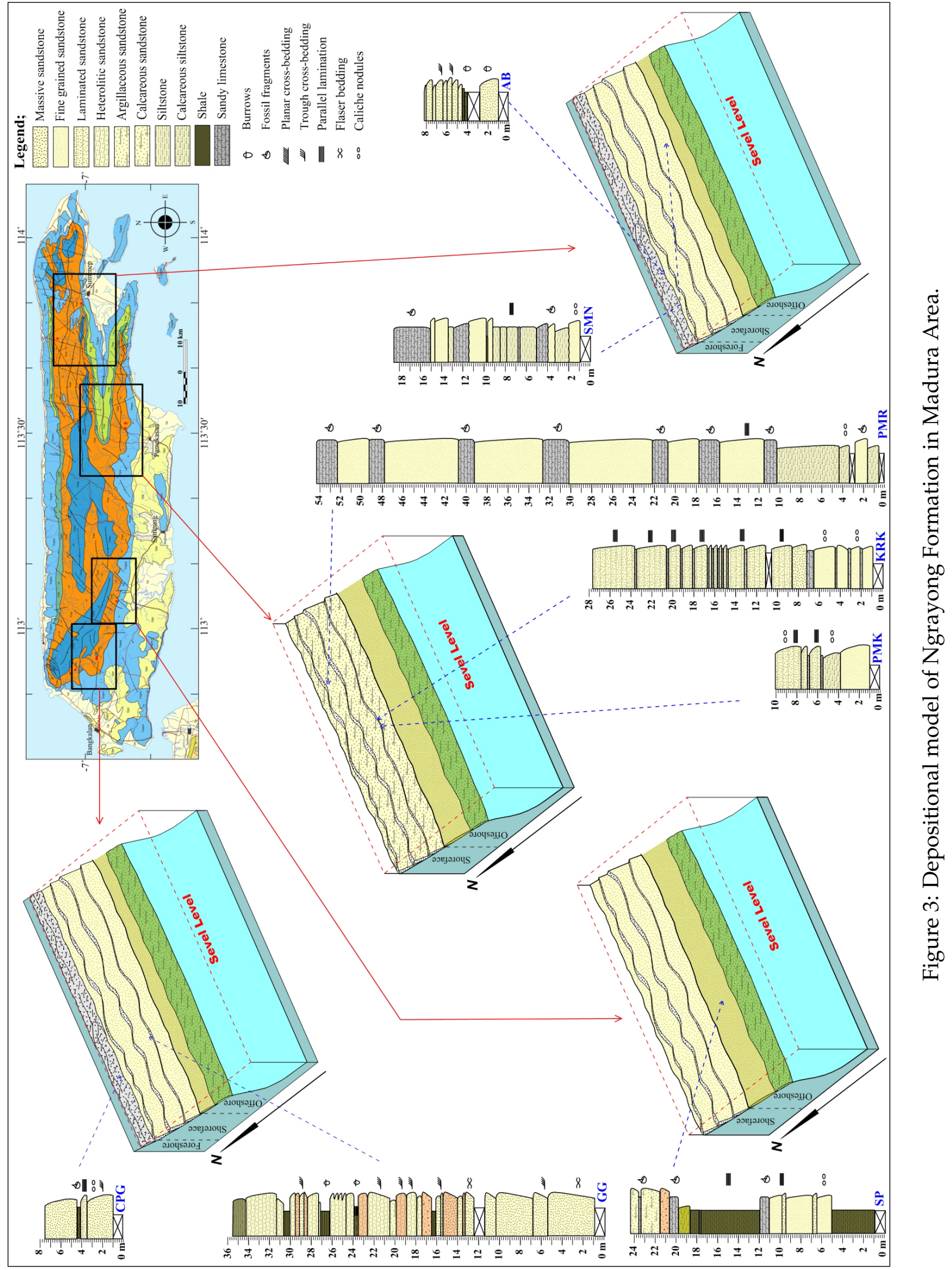



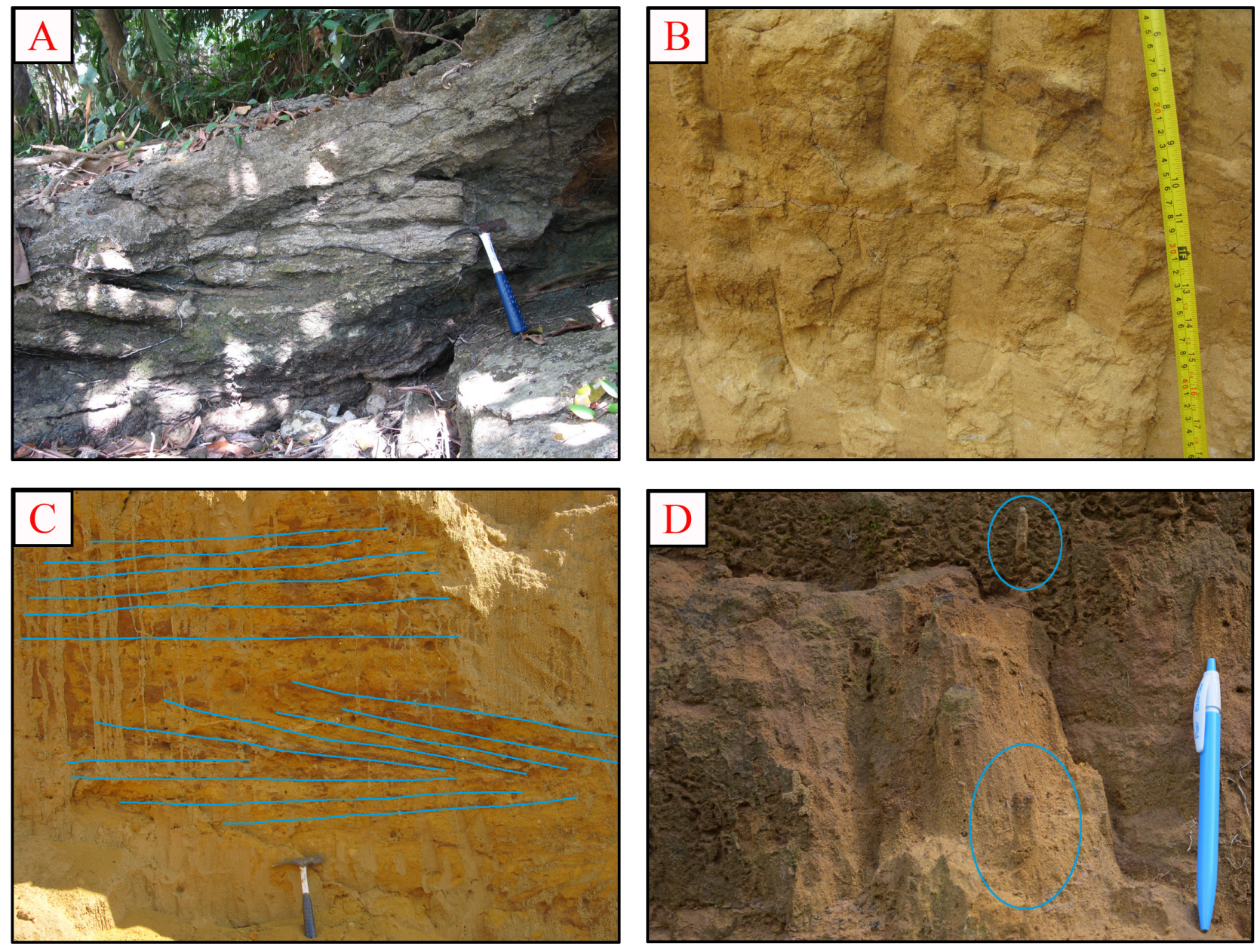

Figure 4: The coastal sediments in Madura Area; (a) Large scale cross-bedding in thickly bedded sandstone, (b) Flaser bedding within the massive sandstone, (c) Parallel laminated sandstone covered over cross bedded sandstone, (d) The vertical burrow structures in massive sandstone. 
bedded silt layer which include lenticular sand laminae. Bi-directional cross-laminated structure is locally found in these sandstones (Figure 5a). These heterolithic sandstones are deposited in lower portion of tidal flat under condition low current speed developed ripple cross-lamination under mix flat produced wavy bedding silty sand and shale (Figure $5 \mathrm{p}$ ). Finegrained, medium to thickly bedded sandstones of this unit are exposed at SMN quarry section (Figure 3) and SP quarry section (Figure 3) in southern part of Madura Island. The primary sedimentary structures such as horizontal and parallel laminated structure are common in the fine grained sandstones.

The similar lithology of fine grained sandstone in SP and SMN sections are encountered in the sandstones of KRK quarry (Figure 3 ) and PMK quarry (Figure 3). But, these sandstones show laminated structure and more calcareous than sandstones in SP and SMN sections. Thin, argillaceous limestone intercalations are occurred in laminated fine grained sandstones (Figure 55). Foraminifera, Cycloclypeus sp, and Lepidocyclina murrayana $s p$. are found in the thin section of laminated sandstone (Figure $5 \mathrm{~d}$ ). In the PMR road section which situated $15 \mathrm{~km}$ northeast direction from KRK quarry section, the sandstones represented similar lithology to laminated sandstone are interbedded with bioclastic limestones (Figure 3). Thin, parallel, horizontal to low inclined laminae (Figure 5e) without reactivation surface reflected suspension sediment deposited in low energy currents in moderate-depth setting are characterized in these fine grained sediments. Where calcareous, coarser-grained, more fossiliferous, and thicker-laminated of these sediments is indicative of a slightly higher energy, lower shoreface environment.

Bioclastic limestones are interbedded with fine grain sandstone in SP quarry, SMN quarry and PMR road sections. These carbonates are dark brown, medium- to thick-bedded, grain supported and fossiliferous sandy limestones (Figure 5f), and contain large foraminifera as Cycloclypeus sp. with other bioclasts. The foraminifera, Cycloclypeus sp. are one of the best paleo-water depth indicators. It occurs rarely in waters as shallow as 70 meters $(225 \mathrm{ft})$ but only becomes frequent or common in about 100 to 120 meters (330-400 ft) of water (J.O.B. Pertamina-Trend Tuban, 1990). The presence of sedimentary structures developed in tidal currents, lithologic characters and fossil evidences interpreted that these sediments are deposited in tide-dominated, upper shoreface to offshore transition environments (Nichols, 1999; Miall, 2000; Nichols, 2009).

\section{Lower shallow marine unit}

This unit is well exposed at at SP quarry section and at the upper portion of GGL quarry section (Figure 3). The lower shallow marine sediments are represented by dark grey mudstones and grey shale. Generally grey, occasionally dark grey and thinly to thickly bedded siltstones are occurred at the GGL section (Figure 3). Dark coloured mudstone contains fine grained, yellowish brown, lenticular sand. Thinly laminated structures are developed in the siltstone beds. Bioturbation and horizontal burrows are common on the upper surface of these siltstone layers (Figure 6a).

The gray shale that crop out at SP section (Figure 3)were thickly bedded to massive, noncalcareous and less fossil content. It includes thin (1-3 mm), slightly lenticular silty laminae. Fissility is common in shale layer (Figure 6b). The laminated and fissile structures, dark colour, very fine grained composition of this sediment are reflected suspension loads fallout in a low energy setting. Based on lithologic characters, horizontal bioturbations and sedimentary structures, these sediments are interpreted as forming from the deposition in offshore or deep shallow marine environment (Nichols, 1999; Miall, 2000; Nichols, 2009).

\section{Conclusion}

The measured sections of Ngrayong Formation were taken in the seven quarry sections and one road section of the study area. Generally, Ngrayong Formation can be divided into three depositional units which possess different sedimentary facies. The coastal unit exposed in the northern part of Madura Area is 

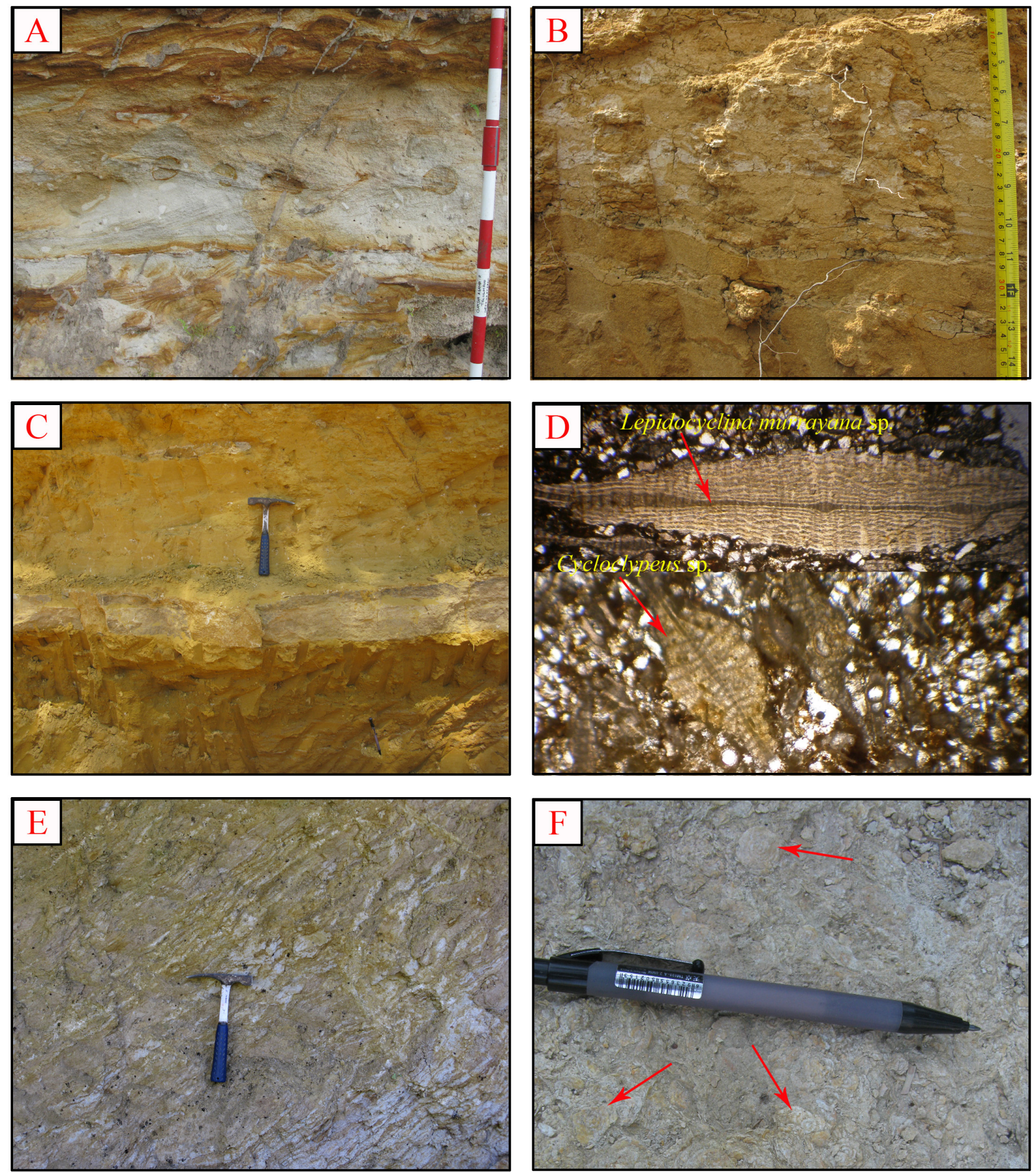

Figure 5: The upper neritic sediments in Madura Area (a) Bidirectional cross-laminae in heterolithic sandstone, (b) The heterolithic sandstone intercalated with mud wavy laminae (c) Fine grained sandstone intercalated with argillaceous limestone (d) Microscopic view of foraminifera, Lepidocyclina murrayana sp. and Cycloclypeus sp., in fine grained, laminated sandstone (f) Bioclastic limestone with Large foraminifera Cycloclypeus sp. 

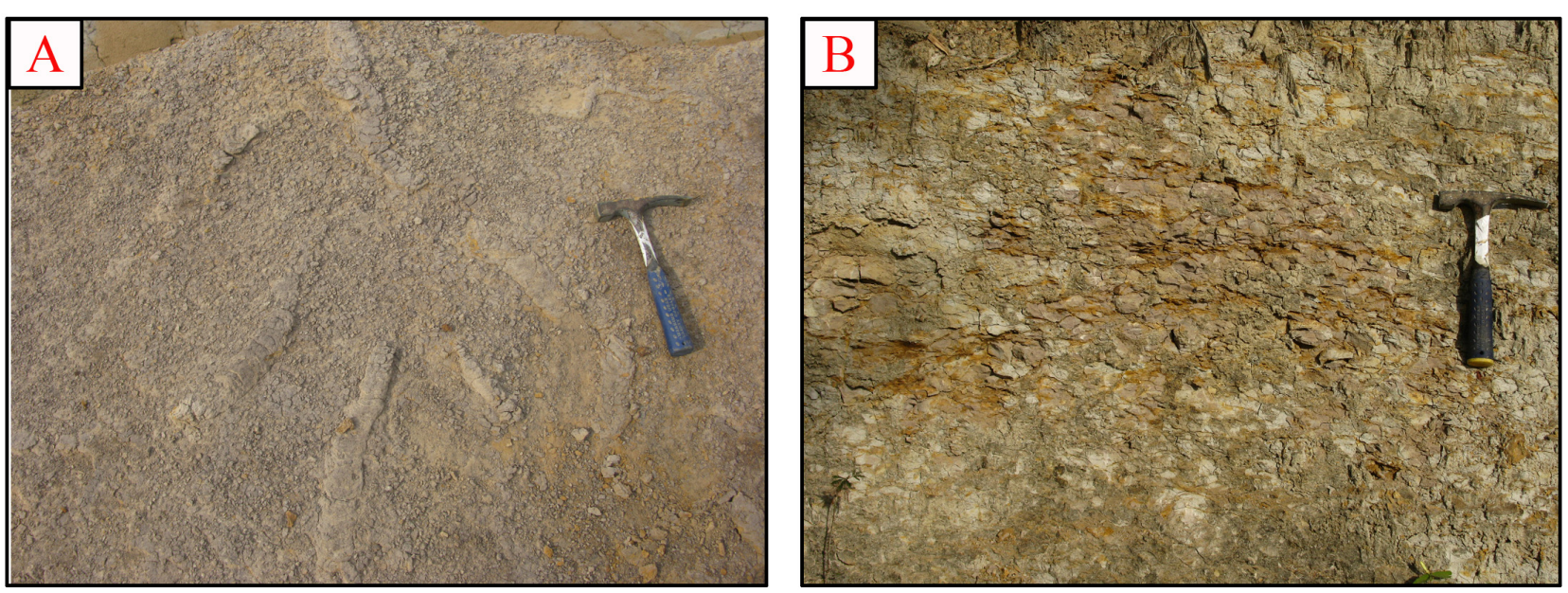

Figure 6: The lower neritic sediments in Madura Area, (a) Horizontal bioturbations on the surface of dark grey siltstone, (b) Fissile structures in grey shale.

deposited in beaches and foreshore environments. The upper shallow marine unit that cropped out in north western part and southern flank of Madura Anticline is deposited in tide-dominated, upper shallow shelf environment. The lower shallow marine unit occurred in southern part of the study area are deposited in moderate-depth lower shallow shelf or offshore environment. The depositional environments of Ngrayong Formation move to the deeper from north to south.

\section{Acknowledgements}

The authors would like to be grateful to the AUN/SEED-Net (ASEAN University Network Southeast Asia Engineering Education Development Network) program and JICA (Japanese International Cooperation Agency) for financial support.

\section{References}

Ardhana, W. (1993) A depositional model for the early Middle Miocene Ngrayong Formation and implications for exploration in the East Java Basin, Proceedings, Indonesian Petroleum Association, twenty second annual convention, pp. 395-441.

Azis, S., Sutrisno, Noya Y., and Brata, K. (1992) Geological Map of Tanjungbumi and Pamekasan Quadrangle, Jawa.
Bouwens, A.L. (1983) Correlation profilesKawengan, B. P. M. report, unpublished.

Brouwer, J. (1957) Stratigraphy of the younger Tertiary in North East Java and Madura, B. P. M. report, unpublished.

Darman H. and Sidi, F.H. (2000) East Java; in An Outline of the Geology of Indonesia, Published by IAGI-2000, pp. 54-59.

Endharto, M.A.C. (2004) the Tidal Flat-Shelf Depositional System of the Ngrayong Sandstone in the Western Part of the Madura, Indonesia Association of Geologist, 33rd Annual Convention \& Exhibition 2004, 33 pp.

IBS (2006) Indonesis Basin Summaries, North East Java Sea Basin and North East Java Basin, pp. 69-94.

J.O.B. Pertamina - Trend Tuban (1990) East Java fieldwork report, five volumes, unpublished.

Latief, R., May P., and Suseno, A. (1990) Indonesian Petroleum Association Post Convention Field Trip 1990 Madura Island, October 19-21, 1990. Guide Book, 79 pp.

Miall, A.D. (2000) Facies analysis: in Principles of Sedimentary Basin Analysis, Springer, Berlin, Germany, pp. 141-248.

Nichols, G.J. (1999) Sedimentology and Stratigraphy, $1^{\text {st }}$ edition, Blackwell Scientific Publications, Oxford, London, UK, 335 pp.

Nichols, G.J. (2009) Sedimentology and Stratigraphy, $2^{\text {nd }}$ edition, Blackwell Scientific Publications, Oxford, London, UK, 419 pp.

Sharaf, E., Simo, J.A., Carroll, A.R., and 
Shields, M. (2005) Stratigraphic evolution of Oligocene-Miocene carbonates and siliciclastics, East Java Basin, Indonesia. AAPG Bulletin 89, 799-819.

Situmorang, R.L., Agustianto D.A., and Suparman, M. (1992) Geological Map of the WaruSumenep Quadrangle, Jawa.

Soetantri, B., Samuel, L., and Najoan, G. A. S. (1973) The geology of Oilfields in North East Java, Proceedings, Indonesian Petroleum Association, second annual convention, pp. 149-175.
Supandjono, J.B., Hasan, K., Panggabean, H., Satria D., and Sukardi (1992) Geological map of the Surabaya and sapulu quadrangle, Jawa.

Yulihanto, B., Sofyan, S., Musliki, S., Wijaya, S., Wijaya, B., and Hastuti, H.W. (1995) Miocene - Pliocene: N.E. Java Basin Sequence Stratigraphy, Indonesian Petroleum Association, Post Symposium Field Trip 1995, 65 pp. 